\title{
VARIASI KELUASAN MAKNA INTERPERSONAL TEKS TRANSLASIONAL LINTAS BAHASA NOVEL BOTCHAN BERBAHASA JEPANG DAN INDONESIA
}

\author{
Christine Dian Permata Sari ${ }^{1)}$, Sufriati Tanjung ${ }^{2)}$ \\ Universitas Teknologi Yogyakarta ${ }^{1)}$ Universitas Negeri Yogyakarta ${ }^{2)}$ \\ chdian3sas@yahoo.com ${ }^{1)}$, sufriati.tanjung@yahoo.com ${ }^{2)}$
}

\begin{abstract}
Abstrak
Penelitian ini bertujuan untuk menganalisis dan mendeskripsikan variasi keluasan makna interpersonal (KMI) teks translasional lintas bahasa novel Botchan berbahasa Jepang dan Indonesia, faktorfaktor penyebab variasi KMI, serta pengaruh variasi KMI terhadap kesepadanan makna teks terjemahan. Penelitian ini adalah penelitian deskriptif-kualitatif. Sumber data primer penelitian yaitu novel Botchan dalam bahasa Jepang (T1) dan bahasa Indonesia (T2) disertai data sekunder berupa hasil wawancara. Data penelitian berwujud klausa yang difokuskan pada makna interpersonal melalui pendekatan Linguistik Fungsional Sistemik dan Komunikasi Semiotik Translasional. Hasil penelitian menunjukkan bahwa 1115 klausa atau 43,58 \% dari jumlah keseluruhan klausa (2562) dalam T2 tersusun dengan jenis dan jumlah elemen makna yang setara dengan T1. Faktor-faktor penyebab variasi KMI T1 dan T2 adalah perbedaan sistem bahasa dan konteks situasi, termasuk konteks budaya. Variasi-variasi KMI yang terjadi sebagai upaya untuk mempertahankan kesepadanan makna antara T1 dan T2.
\end{abstract}

Kata-kata kunci: makna interpersonal, sistem bahasa, konteks situasi, kesepadanan makna

\section{THE INTERPERSONAL MEANING BREADTH VARIATION OF CROSS LANGUAGE TEXT TRANSLATIONAL “BOTCHAN” IN JAPANESE AND INDONESIAN TEXTS}

\begin{abstract}
This study aims to analyze and describe variations of the interpersonal meaning breadth on translational cross-language text of the novel Botchan Japanese and Indonesian language, the factors that cause variations of the interpersonal meaning breadth and the effect of these variations on the meaning equivalence of the translated text. This research is descriptive-qualitative. The sources of primary data research are novel Botchan in Japanese version (T1) and Indonesian version (T2), and the secondary data sources are the result of the free interview. The research data is clauses focusing on the interpersonal meaning to the approach of Systemic Functional Linguistics and Translational Semiotic Communication. The results show that the 1115 clauses or $43.58 \%$ of the total number of clauses (2562) in T2 are composed with the type and number of element meaning equivalent to T1. Factors affecting variation of the breadth of interpersonal meaning $T 1$ and T2 are the differences of language system and situational context, including the cultural context. The variations of the interpersonal meaning breadth that occur in an effort to maintain the equivalence of meaning between $T 1$ and $T 2$.
\end{abstract}

Keywords: interpersonal meaning, language system, situational context, meaning equivalence 


\section{PENDAHULUAN}

Penerjemahan bukan hanya merupakan kegiatan transformasi teks asli (teks sumber) dalam satu bahasa ke dalam teks yang setara dengan bahasa negara-negara lain (teks sasaran) tetapi juga merupakan komunikasi semiotik yang merealisasikan makna dan bentuk dari teks sumber ke teks sasaran. Makna atau pesan yang terdapat dalam suatu teks harus bisa diungkapkan kembali ke dalam teks yang lain. Pemaknaan merupakan langkah awal dalam penerjemahan. Dengan komoditas berwujud pesan atau makna itulah, penerjemahan tidak lain merupakan satu bentuk komunikasi yang melibatkan sistem semiotik yang selalu beroperasi dalam konteks.

Perbedaan konteks yang selalu mewarnai dalam proses pengalihan bahasa suatu teks dapat memicu kemunculan variasi-variasi. Variasivariasi makna yang muncul dapat berupa penambahan, pengurangan, dan penghilangan elemen dari makna adakalanya tidak dapat dihindari. Selanjutnya, variasi-variasi makna ini memunculkan tingkat atau derajat makna, yaitu keluasan (breadth), ketinggian (height), dan kedalaman (depth).

Sytemic Functional Linguistic yang dicetuskan oleh Halliday. Merupakan sebuah pendekatan yang memandang bahasa sebagai semiotik sosial yang digunakan untuk mencapai tujuan menguraikan perspektif fungsional dalam studi terjemahan dari beberapa aspek: karakteristik tekstual, konteks dan bahasa pilihan, hubungan antara makna dan realisasinya adalah teori Terkait dengan fenomena realisasi makna yang variatif maka Komunikasi Semiotik Translational (KST) dianggap sebagai sebuah konsep baru penerjemahan yang menjelaskan bahwa proses penerjemahan sebagai proses pengalihan makna baik secara denotatif (tekstual) yang tertuang sistem tata bahasa atau gramatikal maupun secara makna konotatif (kontekstual) yang terwujud sebagai perwujudan faktor sosial budaya tertentu.

Larson (1984, p.3) memandang penerjemahan sebagai proses pengalihan amanat dari teks bahasa sumber ke dalam teks bahasa sasaran dengan menggunakan bentuk gramatikal dan leksikal bahasa sasaran yang wajar. Larson menekankan pada kesepadanan makna antara teks sumber dan teks sasaran, dimungkinkan penerjemah mengubah struktur bahasa

Halliday (1992, pp.23-32) menjelaskan teori fungsional bahasa melalui analisis suatu kalimat sebagai representasi fenomena dalam dunia nyata yang dipandang memiliki berbagai makna: (1) experiential meaning, (2) interpersonal meaning, (3) logical meaning (4) textual meaning. Makna terjalin secara bersama-sama dalam satu struktur, karena itu memandang makna secara keseluruhan tidak memandang bagianbagiannya secara terpisah. Halliday (1992, p.70) juga menegaskan bahwa teks adalah bahasa yang sedang melaksanakan tugas tertentu dalam konteks situasi. Dengan demikian dapat disimpulkan bahwa makna metafungsional adalah makna yang secara simultan terbangun dari tiga fungsi bahasa, yaitu fungsi ideasional, fungsi interpersonal, dan fungsi tekstual. Fungsi ideasional, fungsi interpersonal, dan fungsi tekstual disebut juga makna ideasional, makna interpersonal, dan makna tekstual. Hal ini dikatakan demikian karena fungsi merujuk kepada makna, karena setiap kata yang berfungsi memiliki makna. Demikian sebaliknya, setiap kata yang bermakna memiliki fungsi.

Makna interpersonal berkaitan dengan interaksi antara pembicara dan pendengar atau antara penulis dengan pembaca. Oleh karena itu, makna interpersonal sangat berhubungan erat dengan proses komunikasi langsung yang berfungsi sebagai alat pertukaran, as exchange. Makna interpersonal dapat diidentifikasi dengan mengenali elemen mood yang terdapat di dalamnya. Dalam struktur gramatika proposisi terdiri atas dua elemen pokok klausa, yaitu Mood dan Residue.

Dalam mood terdapat dua unsur gramatikal yang menjadi pokok dari makna interpersonal, yaitu Subjek dan Finit. Pada Residu terdapat tiga elemen fungsi gramatikal utama, yaitu (a) predikator (Predicator), (b) komplemen (Complement), dan (c) keterangan (Adjunct).

Bahasa sasaran yang menjadi produk atau hasil suatu proses penerjemahan, idealnya adalah merupakan hasil yang sepadan dengan keakuratan pesan dari bahasa sumber, keterbacaan, dan keberterimaan produk. Kesepadanan tersebut meliputi kesepadanan pada tataran leksem (kata), frasa (above word level), gramatikal, tekstual, maupun pada tataran pragmatik. Namun dalam hal ini, Baker menyatakan bahwa keseluruhan tataran tersebut digunakan dengan syarat bahwa meskipun kesepadanan dapat dipraktikkan, hal itu tetap dipengaruhi oleh berbagai faktor linguistik dan budaya; yang oleh karena itu sifatnya adalah relatif. Seperti yang diungkapkan Baker (1992, p.6) berikut ini: " It is used here with the proviso that although 
equivalence can usually be obtained to some extent, it is influenced by a variety of linguistic and cultural factors and is therefore always relative."

Berdasarkan pandangan atau konsep yang menyatakan bahwa penerjemahan merupakan penempatan atau representasi suatu teks yang ekuivalen dari suatu bahasa ke bahasa lainnya, maka dapat disimpulkan bahwa teks bahasa yang berbeda dapat menjadi sepadan pada tingkatan yang berbeda; baik secara keseluruhan, maupun sebahagian dalam kaitannya dengan konteks semantik, sintaksis, leksem, dan lainlain; serta dalam tingkatan penerjemahan kata demi kata, frasa demi frasa, dan klausa demi klausa. Seperti yang diungkapkan Bell (1991, p.6) berikut ini:

Text in different language can be equivalent in different degrees(fully or oartially), in respect of different level of presentation (equivalent in respect of context, of semantics, of grammar, of lexis, etc) and at different rank (word-for-word, phrase-for-phrase, sentence-for-sentence).

Ide penelitian ini dilatarbelakangi oleh permasalahan yang pasti muncul dalam penerjemahan adalah bagaimana makna-makna dalam karya asli dapat dikemas menjadi bahasa tekstual dengan konteks budaya yang berbeda. Dengan alasan tersebut, kajian tentang perwujudan makna dengan sudut pandang tatabahasa fungsional dari karya sastra atau novel "Botchan" karya Natsume Soseki ke dalam karya terjemahan lintas bahasa yang diberi judul sama akan menjadi kajian yang layak untuk dilakukan. Makna interpersonal menjadi fokus penelitian ini terkait dengan kajian novel "Botchan" karya Natsume Soseki sebagai teks sumber (T1), dan novel "Botchan" karya terjemahan Indah Sari Pratidina sebagai teks sasaran (T2) dengan rincian topik sebagai berikut: (a) bagaimana wujud variasi keluasan makna interpersonal T1 dan T2?, (b) faktor-faktor apa saja yang menyebabkan terjadinya variasi keluasan makna interpersonal pada T2?, (c) bagaimanakah pengaruh adanya variasi keluasan makna interpersonal terhadap kesepadanan makna T2?

Kajian ini diharapkan dapat memberikan bukti empirik bahwa ternyata penerjemahan ternyata tidak hanya dihasilkan dengan memadankan unsur-unsur sintaksis dan semantik yang berlaku di dalam bahasa sumber dengan padanan masing-masing di dalam bahasa sasaran tetapi juga menyertakan aspek fungsional.

\section{Pembahasan}

Bagian ini membahas temuan-temuan di atas dengan berfokus pada fitur-fitur temuan yang menonjol dan dianggap penting untuk disajikan, dari wujud variasi KMI berupa penambahan dan pengurangan elemen makna interpersonal pada T2, tingkat variasi keluasa-an makna KMI pada keseluruhan klausa T2, faktor-faktor penyebab KMI, serta pengaruh variasi KMI tersebut terhadap kesepadanan makna T2.

\section{Wujud Variasi KMI dalam T1: T2}

Dari hasil data analisis KMI berupa varian satu hingga varian lima diketahui bahwa variasi tersebut disebabkan adanya penambahan dan pengurangan atau penghilangan elemen baik berupa Subjek (S), Predikator (P), Komplemen (K), Adjung (A) maupun Finit (F) pada T2. Jumlah elemen dari masing-masing klausa T1 dan T2 dihitung, dan jumlah elemen predikator yang muncul menjadi acuan dalam menentukan klausa simpleks atau klausa kompleks. Misalnya;

$$
\begin{aligned}
& \mathrm{T} 1: \stackrel{\text { オヤユズ }}{\text { 親譲りの }} \\
& \text { ムテッポウ, 無鉄砲で小供の時から } \\
& \text { Adjung Adjung } \\
& \text { 損ばかり している。 }
\end{aligned}
$$

\section{T2: $\underline{\text { Sejak aku kecil, kecerobohan alamiku }}$}

$$
\begin{aligned}
& \text { Adjung Subjek } \\
& \text { selalu memberiku masalah. } \\
& \text { Predikator-Adjung-komplemen- }
\end{aligned}
$$

Artinya, dengan melihat jumlah elemen pada klausa T1 diketahui bahwa T1 terdiri dari 2 (dua) elemen adjung, 1 (satu) elemen komplemen, dan 1 (satu) elemen predikator. Klausa T1 merupakan klausa simpleks karena di dalamnya hanya terdapat satu elemen predikator. Demikian pula pada penghitungan jumlah elemen pada T1. Klausa T2 pun hanya memiliki 1 (satu) elemen predikator artinya T2 pun merupakan klausa simpleks. Namun, karena pada T2 terdapatnya 1 (satu) elemen subjek, maka pada penerjemahan T2 muncul variasi KMI yaitu berupa penambahan elemen subjek. Dengan demikian, klausa pada T2 tersebut merupakan varian satu. 


\section{Penambahan elemen makna interpersonal} antara T1:T2

Hasil analisis pada seluruh klausa menunjukkan bahwa penambahan elemen berupa subjek (S) merupakan elemen yang paling banyak hadir pada varian-varian tersebut. Sebagian besar variasi KMI berupa penambahan subjek bukan disebabkan karena perbedaan sistem kebahasaan, tetapi lebih banyak karena perbedaan pola budaya berbahasa antara bahasa Jepang dan kedua bahasa. Jika diperhatikan pola kalimat kedua bahasa ini elemen subjek dan predikat merupakan elemen yang penting untuk membentuk suatu kalimat. Selain itu pun, terdapat kesamaan lainnya adalah dalam membangun suatu kalimat pada sistem ketatabahasaan pada pembentukan kalimat dari kedua bahasa predikat adalah unsur fokus atau inti kalimat. Namun, ada pula perbedaan, salah satunya adanya elemen partikel dalam susunan kalimat bahasa Jepang. Penambahan subjek tersebut merupakan penambahan wajib dalam bahasa Indonesia untuk membentuk klausa simpleks maupun kompleks sesuai tatabahasa Indonesia.

Dalam korpus data sangat banyak ditemukan kasus-kasus penambahan, seperti yang disajikan pada sampel data dari masing-masing varian. Misalnya, klausa berikut ini adalah klausa bervarian dua.

\section{(1) T1: だから婆さんである。 dakara obaasan dearu.}

T2: Itulah sebabnya kini dia adalah wanita tua biasa.

Penambahan subjek "dia" pada contoh (1) merupakan penambahan wajib dalam bahasa Indonesia untuk membentuk klausa simpleks baku sesuai tatabahasa Indonesia. Dalam bahasa Jepang subjek tidak perlu diulang pada kalimat berikutnya, apabila pada kalimat awal telah diungkapkan. Penambahan wajib dilakukan pada kata "kini", merupakan penerjemahan dari kopula dearu yang dipakai untuk menyatakan keadaan yang terjadi di waktu sekarang. Pada beberapa data lainnya kasus penambahan kala tidak dilakukan penerjemah karena dalam bahasa Indonesia kala tidaklah ditandai secara gramatikal, namun pada data tersebut penambahan kala "kini" menjadi penting dilakukan karena klausa tersebut terkait dengan klausa sebelumnya yang menceritakan tentang perubahan dari "dia" yang "bukan wanita biasa".
Penambahan subjek baik berupa pronomina, maupun kata lainnya hadir pada sebagian besar klausa sehingga menyebabkan adanya varian 1 hingga varian 5. Variasi juga bisa muncul karena ketiadaan finit pada klausa dalam bahasa Indonesia sehingga sering kali dipakai kata yang menyatakan kala/waktu sebagai keterangan atau adjung.

Penambahan komplemen umumnya karena akibat perbedaan gramatikal dalam membentuk predikator. Misalnya, Verba "suru" mengandung banyak arti diantaranya "melakukan", "mau" dan "mempunyai atau pembentuk awalan "ber-" pada kata "berwajah", "bersuara" atau "berbau", dan lain-lain.

\section{(2) T1: 山嵐は ミョウ,妙な顔をしていた。}

Hotta wa myouna kao o shite ita. (literal: Hotta berwajah aneh)

T2: Dia menatapku aneh.

Penambahan elemen predikator pada klausa T2 menyebabkan perubahan tipe klausa simpleks menjadi klausa komplek. Sebagian besar perubahan ini dapat mempertahankan makna pada T1, seperti tampak pada klausa berikut ini.

\section{(3) T1 : 妙なおやじがあったもんだ。} myouna oyajiga atta monda.

T2: Tidak ada penjelasan lain, ayahku orang aneh.

Klausa di atas merupakan klausa simpleks dengan predikator yang berupa frasa kata benda "atta monda" yang bermakna "suatu alasan yang ada", dan komplemen berupa frasa kata benda "myouna oyaji" yang bermakna "ayahku (orang) yang aneh", maka elemen tersebut dirangkai menjadi kalimat atau klausa simpleks menjadi "adanya suatu alasan (tentang) ayahku yang aneh". Penerjemahan klausa tersebut menghasilkan selain perubahan bentuk pada tingkat klausa juga menghasilkan pergeseran pada tingkat frasa "ayahku yang aneh" menjadi klausa "ayahku orang aneh". Walaupun terjadi perubahan bentuk dan penambahan predikator, frasa "orang aneh" menjadi predikator tambahan, selain predikator pertama "tidak ada", penerjemahan T2 dapat mempertahankan kesepadanan makna T1.

Dalam bahasa Jepang atau T1 struktur mood, karena ketiadaan elemen subjek pada sebagian besar klausanya, sedangkan dalam bahasa Indonesia atau T2, karena tidak adanya elemen finit maka penambahan elemen subjek ini menjadi elemen mood. 
Penambahan klausa atau lebih tepat dikatakan sebagai penciptaan klausa pada T2 adalah merupakan bentuk upaya penterjemah dalam menciptakan keberterimaan penerjemahan yang dilakukannya. Perbedaan sistem bahasa dalam mengungkapkan makna atau realitas menyebabkan penterjemah harus meletakkan klausa baru yang dalam teks sumber, makna itu dipahami eksplisit. Penciptaan klausa ini menjadi bersifat subjektif. Klausa berikut ini menunjukkan bahwa penterjemah berupaya memberikan kesimpulan dari percakapan Botchan dan Kiyo yang dimulai dari klausa 0220/ T1/I sampai dengan 0230/T1/I.

- 0231/T2/I Wanita seperti ini memang hanya bisa membuatmu putus asa.

Pengurangan Elemen Makna Interpersonal Antara T1:T2

Dalam proses pemadanan terjadinya kasus pengurangan elemen struktural lebih terbatas dan bersifat penghilangan manasuka sejumlah elemen struktur untuk menghindarkan atau membatasi kemubasiran dan repetisi. Berikut adalah contoh data-data yang teridentifikasi adanya pengurangan:

\section{（4） T1: 事務員に聞いてみるとおれは}

\section{ここへ降りるのだそうだ。}

Jimuin ni kiitemiruto orewa koko $e$ orirunodasouda.

T2 :_Aku diberitahu kepala keuangan kapal bahwa di sinilah tempat aku harus turun.

Pengurangan atau lebih cocok penghilangan unsur predikat dalam T2sebagai padanan zero, kata "- souda" dalam T1 didasarkan atas pemikiran kewajaran ungkapan yang dimaksudkan untuk menghindari repetisi karena dalam klausa sebelumnya sudah dinyatakan "jimuin $n i$ kiitemiru". Klausa (a) menunjukkan juga terjadi pergesesran bentuk klausa dari bentuk transitif aktif menjadi bentuk pasif.

（5） T1:山嵐は大きな声をしてアハハハと笑

いながら、そんなら、なぜ早く

取らなかったのだと聞いた。

Hotta wa ookina koe o shite ahahaha to warainagara, sonnara, naze hayaku toranakatta-noda to kiita
T2: Hotta tertawa terbahak-bahak dan berkata, "Kenapa tidak kau ambil lebih cepat?"

Bila dicermati pada klausa (5) terjadi pengurangan pada tingkat frasa pada T2 (ookina koe o shite) yang berarti "bersuara keras", pemadanan dilakukan dengan mendes-kripsikan "ahahaha to warainagara" dengan tertawa terbahak-terbahak. Pengurangan ini untuk menghindari kemubasiran makna terbahakbahak berarti pula tertawa dengan suara yang keras.

(6) T1: Hotta o sasoinikitamonowa dareka to omottara Akashatsuno otoutoda.

T2: Anak yang mencari Hotta ternyata adik Kemeja Merah.

Pada contoh (6) pengurangan frasa "dareka to omottara" (ketika kupikir siapakah) direalisasikan dengan kata "ternyata" untuk mengungkapkan makna kepastian dari kopula "da". Pada contoh (6) ditemukan pergeseran pada kata "otouto" yang bermakna denotatif "adik laki-laki saya" dipadankan dengan kata "adik". Pada konteksnya pergeseran ini bisa saja terjadi tanpa menyebutkan jenis kelamin ketika diketahui nama orang tersebut.

Penghilangan berupa klausa yang merupakan variasi KMI paling tinggi yakni varian 6. Bila dicermati penghilangan yang dilakukan penerjemah $\mathrm{T} 2$ atas realisasi yang terdapat pada T1 disebabkan makna-makna itu secara tersirat sudah memadai dengan mengandalkan konteks yang mengelilinginya. Dengan kata lain, secara intrinsik realisasi klausa pada T2 sudah cukup memadai untuk mengungkapkan satu makna yang dimaksud oleh T1 sebagai konteks intertekstual dari klausa tersebut. Tidak sedikut pula klausa yang tidak dapat diterjemahkan atau dikelompokkan pada varian enam. Ada 29 klausa yang masuk kelompok varian enam, hal in dapat menjadi bukti ketakterjemahan T1 terhadap T2.

（7） T1:おれのはいった団子屋は遊廓の入口 に

あって、大変うまいという

評判だから、温泉に行った帰りがけ にちょっと食ってみた。

Ore no haitta dango-ya wa yūkaku no iriguchi ni atte, taihen umai to iu hyōbandakara, onsen ni itta kaerigake ni chotto kutte mita.

T2 : - 
Penghilangan klausa atau tidak diterjemahkannya klausa tersebut sudah pasti akan menyebabkan pembaca T2 bertanya-bertanya mengapa kedatangan Botchan ke toko dango menimbulkan protes para murid terhadap Botchan, yang kemudian menjadi masalah besar. Dari klausa tersebut seharusnya pembaca T2 dapat menginterprestasikan masalah yang terjadi antara Botchan dan para murid, mungkin salah satunya adalah karena mereka mengira Botchan pergi ke rumah bordil juga sebelum makan di toko dango itu.

\section{Tingkat Variasi Keluasan Makna Interpersonal pada Keseluruhan Klausa T2}

Jumlah klausa pada sumber data sebanyak 2562. Berdasarkan analisis yang dilakukan, diketahui bahwa penghitungan jumlah klausa dan jumlah elemen fungsi pada setiap klausa antara $\mathrm{T} 1$ dan T2, antara teks berbahasa Jepang dan teks berbahasa Indonesia, mendekati prosentase $50 \%$ atau tepatnya $43,58 \%$ memperlihatkan tingkat variasi rendah. Perbedaan prosentase kecil atau $32,58 \%$ pada tingkat variasi sedang dan 23, 84\% merupakan tingkat variasi tinggi. Artinya, melalui KMI yang setara, T2 sangat dipengaruhi oleh T1 sebagai konteks dalam kontruksi makna T1 berupa elemen-elemen fungsi yang membentuk mood dan residu. Menurut Bell (1991, p.11) untuk mempertahankan makna terdapat "tiga hukum", yakni model, meaning, memory dari definisi terjemahan Tyler juga merumuskan prinsip-prinsip serupa: (1) penerjemahan harus menyampaikan seluruh gagasan dari karya asli, (2) gaya dan cara penulisan juga harus sekarakter dengan aslinya, (3) penerjemahan harus (bisa dibaca) dengan mudah sebagaimana karangan asli. Pencipta T2 berupaya untuk menghadirkan makna-makna pada T1 secara utuh, dengan gaya dan pilihan kebahasaan yang disesuaikan dengan pemahaman, cara pandang dan budaya orang Indonesia, mengingat pencipta karya T2 adalah orang orang Indonesia. Fakta lain yang menarik terlihat dari prosentase pada varian nol sebanyak $9,46 \%$ lebih besar dari prosentase varian 6 dengan 1,41\% serta berbeda sedikit dengan varian 4 dengan $11,59 \%$ membuktikan keterikatan T2 terhadap konteks intertekstualnya.

\section{Faktor-faktor yang Menyebabkan Terjadi- nya Variasi Keluasan Makna Interpersonal (KMI) pada T2}

Dari hasil analisis data diketahui pula bahwa ada dua faktor yang menyebabkan terjadi variasi KMI, yaitu faktor linguistik dan faktor non linguistik. Faktor linguistik adalah faktorfaktor yang disebabkan karena adanya perbedaan sistem kebahasaan pada bidang semantik berupa makna denotatif dan konotatif, serta sintaksis atau gramatika atau tatabahasa antara $\mathrm{T} 1 \mathrm{dan}$ T2. Sedangkan, Faktor nonlingusitik difokuskan pada konteks situasi, terutama konteks budaya dari kedua teks. Pada konteks budaya variasivariasi menunjukkan adanya perbedaan penyampaian pesan terkait pada hubungan antar persona, berupa prinsip dan sikap bahasa pelibat dan tingkat kesantunan bahasa pelibat.

\section{Perbedaan Sistem Kebahasaan antara T1 dan T2 Menjadi Faktor Penyebab Variasi KMI pada $T 2$}

Sintaksis yang terkait dengan makna interpersonal adalah elemen yang membentuk kalimat. Susunan kalimat dalam bahasa Indonesia adalah Subjek-Predikator-Objek (S-P-O), sedangkan dalam bahasa Jepang adalah elemen subjek dianggap sebagai konstituen Subjek-Objek-Predikator (S-O-P). Dalam bahasa Jepang, banyak ditemukan kalimat yang me-nunjukkan keberadaannya subjek disisihkan. Hal ini dapat dimaklumi jika melihat keberadaan subjek dalam bahasa Jepang sebagai bagian sangat penting dalam sebuah kalimat, tetapi hal itu pun tidak menjadi syarat mutlak. Sedangkan, dalam bahasa Indonesia, suatu pernyataan merupakan kalimat, jika di dalam pernyataan itu sekurangkurangnya terdapat predikat dan subjek.

Perbedaan yang mendasar dari susunan elemen dari kedua teks diantaranya adalah finit. Walaupun finit pada kedua bahasa terjalin bersama dalam verba, namun verba dalam bahasa Indonesia tidak terkait atau tergantung dengan kala. Hal ini menjadikan permasalahan dalam mengkaji finit dari kedua teks. Pada varian 0, finit pada $\mathrm{T} 1$ diabaikan pada perbe-daan elemen pada T2.

\section{(8) T1: Kantaroo wa muron yowamushi dearu.} (kala= sekarang)

T2: Kantarô adalah, tentu saja, seorang pengecut.

Kemunculan varian 1 sampai dengan varian 5 dipicu oleh kesenjangan tatabahasa antara bahasa Indonesia dan bahasa Jepang. Salah satu perbedaan yang menonjol dari kedua sistem adalah realisasi mood klausa. Dalam hal ini, kasus yang terjadi adalah variasi penambahan elemen subjek, yang merupakan unsur penting dalam mood blocks. 
Pada sebagian besar klausa makna interpersonal bahasa Jepang ditemukan bahwa mood blocks hanya diwakili oleh finit. Hal ini karena verba sebagai predikator mengalami perubahan bentuknya tergantung dari finit yang hendak diungkapkan penutur. Klausa bahasa Indonesia (T2) merealisasikan mood blocks melalui Subjek saja, karena T2 tidak mempunyai perubahan kala seperti $\mathrm{T} 1$ atau kala diwujudkan bersama dengan verba (predikator). Dengan demikian, konsep tatabahasa dalam T2 mempengaruhi mood blocks. Perbedaan ini mempengaruhi jumlah elemen pada masing-masing teks dan variasi KMI.

Kemunculan variasi KMI pun dipicu oleh kesenjangan wujud interaksi pada penutur T1 dan T2. Salah satu perbedaan yang menon-jol dari kedua sistem bahasa adalah realisasi modus/tipe interogatif. Dalam hal ini sering muncul penambahan elemen "kata tanya atau Wh interogatif' sebagai adjung. Karena bahasa Indonesia mewujudkan kalimat tanya/interogatif dengan menyertakan "kata tanya diawal kalimat" khususnya dalam bahasa formal tidak demikian dengan bahasa Jepang. Klausa interogatif bahasa Jepang ditandai adanya partikel $k a$ setelah finit.

(9) T1: Teishu ga kimi ni nani o hanashita nda $\mathrm{ka}$, ore ga shitteru mon $\mathrm{ka}$.

T2: "Bagaimana aku bisa tahu apa yang dikatakan si pemilik rumah kepadamu?

Modus imperatif bahasa Indonesia direalisasikan dengan predikator di depan klausa dengan atau tanpa subjek, sedangkan dalam bahasa Jepang modus imperatif ditentukan dengan perubahan bentuk verba.

$$
\begin{aligned}
& \text { 「なに今夜はきっとくるよ。一一おい見 } \\
& \text { ろ見ろ」と小声になったから、おれは思 } \\
& \text { わずどきりとした。 }
\end{aligned}
$$

"Tidak perlu cemas, dia akan datang malam ini .....Hei, lihat! Lihat itu!" Suara Hotta melemah hingga menjadi bisikan, jantungku seakan berhenti berdetak.

Perbedaan lainnya adalah pemakaian partikel (kata kerja bantu) dalam bahasa Jepang sebagai penunjuk fungsi elemen-elemen dalam frasa dan kalimat, tetapi dalam bahasa Indonesia tidak ada partikel sebagai kata kerja bantu, tetapi ditemukan kata depan. Partikel dalam bahasa Jepang diletakkan di belakang kata atau frasa. Kala dan aspek selalu menyertai verba dalam bahasa Jepang. Perubahan verba ditentukan oleh kala aspek, maupun modalitas. Kalimat bahasa
Indonesia menempatkan kala atau aspek dan modalitas terpisah dari verba.

\section{(10) $\mathrm{T} 1$ : 県庁も見た。}

\section{Kenchō mo mita.}

\section{Verba + kala lampau}

T2: Aku_melihat kantor pemerintah daerah dan barak-barak tentara.

Penambahan subjek "aku"

Makna interpersonal diwujudkan dengan kesesuaian konstekstual dan perbedaan susunan elemen-elemen fungsional gramatika antara kedua teks untuk menghasilkan kesepadanan makna. Hasil analisis menunjukkan bahwa sebagian besar dari kedua teks didominasi oleh klausa tipe deklaratif dengan modalitasnya. Perbedaan gramatika antara kedua teks kadang menghasilkan penerjemahan klausa dengan modalitas yang berbeda. Namun, perbedaan modalitas tersebut dapat menghasil-kan penerjemahan yang dapat diterima oleh pembaca $\mathrm{T} 2$.

Variasi yang muncul akibat penerjemahan klausa simpleks pada T1 menjadi klausa kompleks dengan dua atau lebih klausa simpleks banyak mempengaruhi pengelompokan klausa pada varian 3, varian 4 dan varian 5. Dalam gramatika bahasa Jepang terdapat perubahan bentuk kata, dan kata yang mengalami perubahan adalah verba, adjektiva dan kopula. Perubahan bentuk ini akan berpengaruh terhadap makna. Salah satu perubahan bentuk verba yaitu bentuk TE. Perubahan verba bentuk TE mempunyai beberapa fungsi dalam membentuk kalimat, diantaranya untuk menyambungkan dua atau lebih kalimat menjadi satu kalimat seperti pada pola berikut ini Subjek-Objek-Predikat (verba bentuk TE), objek-predikat (verba bentuk TE), objekVerba. Verba di akhir kalimat diubah sesuai dengan kala dari kalimat. Dari penjelasan tersebut diketahui bahwa adanya perbedaan dalam menyatakan klausa kompleks dalam bahasa Indonesia.

Pola kalimat yang berbeda dari kedua bahasa, terutama letak predikat mempunyai pengaruh yang signifikan terhadap penerjemahan klausa kompleks T1 menjadi dua atau lebih klausa kompleks, bahkan menjadi lebih dari klausa kompleks T2, seperti pada kalimat berikut ini:

(11) T1:

$$
\begin{aligned}
& \text { それから神楽坂の毘沙門の縁日で八 } \\
& \text { 寸ばかりの鯉を針で引っかけて、し } \\
& \text { めたと思ったら、ぽちゃりと落とし } \\
& \text { てしまったがこれは今考えても惜し }
\end{aligned}
$$


いと云ったら、赤シャツは頑を前の 方へ突き出してホホホホと笑った。 sorekara Kagurazaka no Bishamon no en'nichi de yaki bakari no koi o hari de hikkakete, shimeta to omottara, pochari to otoshite shimattaga kore wa ima kangaete mo oshi to yuttara, aka shatsu wa ago o mae no kata e tsukidashite hohohoho to waratta.

T2: Kali lain, di perayaan yang dilaksana-kan di depan kuil Bishamon di kom-pleks kuil Zenkokuji, Kagurazaka, aku berhasil memancing ikan koi yang besarnya enam belas sentimeter, tapi ketika aku berusaha menangkapnya, ikan itu berhasil lepas dan kembali menyebur ke air. Detik ini pun, aku masih merasa kesal bila mengingat kejadian itu. Aku menceritakan semua ini ke Si Kemeja Merah, tapi dia hanya memajukan dagunya dan menyuarakan tawa yang dibuat-buat.

Apabila klausa kompleks T1 diurai menjadi klausa simpleks menghasilkan 6 klausa simpleks seperti berikut ini: (a) sorekara Kagurazaka no Bishamon no en'nichi de yaki bakari no koi o hari de hikkakete,(b) shimeta to omottara, (c) pochari to otoshite shimattaga, (d) kore wa ima kangaete mo oshī to yuttara, (e) aka shatsu wa ago o mae no kata e tsukidashite, (f) hohohoho to waratta.

Klausa (a), (b), (c) diterjemahkan menjadi satu klausa kompleks dengan penambahan elemen subjek "aku", "ikan itu"; komplemen "nya"; adjung "di depan"; "ke air", "kembali"; dan predikator "menyebur" pada klausa "Kali lain, di perayaan yang dilaksanakan di depan kuil Bishamon di kompleks kuil Zenkokuji, Kagurazaka, aku berhasil memancing ikan koi yang besarnya enam belas sentimeter, tapi ketika aku berusaha menangkapnya, ikan itu berhasil lepas dan kembali menyebur ke air." Klausa (d) diterjemahkan menjadi satu klausa simpleks "Detik ini pun, aku masih merasa kesal bila mengingat kejadian itu"; dengan penambahan subjek "aku" dan penghilangan elemen subjek "kore" yang berarti "hal ini". Klausa (e) dan (f) diterjemahkan menjadi satu klausa kompleks "Aku menceritakan semua ini ke Si Kemeja Merah, tapi dia hanya memajukan dagunya dan menyuarakan tawa yang dibuat-buat" dengan tidak hanya penambahan elemen tetapi berupa klausa "Aku menceritakan semua ini ke Si Kemeja Merah", dan pergeseran bentuk berupa bunyi tawa "hohohoho"menjadi frasa "tawa yang dibu- at-buat". Variasi yang muncul pada klausa tersebut menjadi penentu bahwa klausa tersebut masuk pada kelompok varian 5 .

Hasil analisis data tersebut menunjukkan bahwa perbedaan sistem kebahasaan antara ke dua bahasa sangat mempengaruhi perubahan jumlah elemen makna interpersonal pada $\mathrm{T} 2$. Namun demikian perubahan jumlah elemen yang berupa penambahan dan penghilangan merupakan penerjemahan yang wajib untuk menyesuaikan stuktur bahasa, pola kalimat pada T2.

\section{Perbedaan Budaya antara T1 dan T2 Menjadi Faktor Penyebab Variasi KMI pada T2}

Penambahan elemen subjek mendominasi sebagian besar klausa. Dalam percakapan sering kata "watashi", "ore" atau "saya" dan "anata", "kimi" atau "anda/kamu" sering dihilangkan karena dalam pembicaraannya sudah jelas siapa pembicara dan siapa lawan bicara. Hal ini berbeda dengan percakapan dalam bahasa Indonesia walaupun sudah jelas siapa pembicara dan lawan bicaranya tetap saja menggunakan kata "saya", "aku" atau "kamu", "anda". Dua informan, Yasuhisa Adachi dan Junko Higashi mengungkapkan bahwa dalam percakapan sehari-hari, kalimat bahasa Jepang tidak bersubjek adalah suatu hal yang biasa atau sudah menjadi budaya berbahasa di antara orang Jepang. Junko Higashi menambahkan bahwa ketika percakapan antar dua pelibat, maka tidak menggunakan kata ganti orang "saya" atau "kamu".

Berdasarkan teori KST, KST akan selalu muncul saat seseorang memaknai sesuatu dan menafsirkan sesuatu. Proses penafsiran tersebut kemudian diungkapkan melalui sistem denotatif semiotik bahasa sesuai dengan sistem konotatif bahasa atau kontekstual. Mengacu pada teori KST tersebut dapat ditarik kesimpulan bahwa munculnya variasi KMI pada T2 disebabkan oleh adanya perbedaan cara pandang terhadap konteks antara penerjemah T1 dan penerjemah T2. Sistem denotatif semiotik bahasa, baik itu pada bidang semantik maupun sintaksis diantara ke dua bahasa sangat berbeda. Misalnya pada kata "chichi" dan "oyaji" yang berarti "bapak(ku) "atau "ayah(ku)", makna denotatif kedua kata itu sama, karena merujuk pada objek yang sama, tetapi dalam pemakaiannya kata "chichi" maupun "oyaji" hanya digunakan untuk menyebutkan "ayah-ku" atau "bapakku". Untuk menyebutkan ayahmu atau ayahnya dipakai kata "otousan". Dalam bahasa Indonesia kedua kata tersebut memiliki pemakaian yang sama. Kata "chichi" digunakan lebih formal dan lebih halus, 
sedangkan kata "oyaji" terkesan lebih dekat dan lebih akrab.

(12) T1:

母が死んでからは、おやじと兄と三人

$$
\text { でクラ,暮していた }
$$

Haha ga shindekara wa, oyaji to ani to san" nin de kura shite ita.

T2: Setelah ibu meninggal, aku tinggal bersama Ayah dan kakakku.

Klausa tersebut memunculkan variasi KMI berupa penambahan elemen subjek "aku" dan penghilangan adjung "sannin" yang berarti "bertiga".

Klausa berikut memberi gambaran tentang makna konotatif dari masing-masing teks.

(13) T1 :田舎者の癖に人を見括ったな。 Inakamono no kuse ni hito o mi kukutta na.(jangan memandang orang dengan nyata sebagai orang kampung) Dasar tak tahu malu, memandang rendah orang padahal dirinya sendiri hanya orang kampung!

Penutur pada T1 tidak secara terbuka dalam mengungkapkan "penghinaan", sedangkan penutur pada T2 secara jelas memperlihatkan sikap bahasa yang jelas pada pandangan yang tidak sejalan atau tidak sepaham. Orang Jepang selalu berhati-hati untuk menyampaikan perasaan, hal ini untuk menjaga wa (harmoni, keselarasan, kedamaian) tetap hidup. Masyarakat Jepang berusaha untuk tidak terlalu terbuka dalam mengekspresikan keinginan dan pendapat pribadinya.

(14) $\mathrm{T} 1$ :

向うで部屋へ持って来てお小遣いが なくてお困りでしょう、お使いなさ いと云ってくれたんだ。

Mukō de heya e motte kite o kodzukai ga nakute o komarideshou, otsukai nasai to yutte kureta nda.

T2:Dia membawa uang itu ke kamarku dan berkata, "Kau pasti membutuhkan uang saku. lni, ambil ini."

Penggunaan imbuhan berupa awalan "o" pada "okodzukai" yang berarti "uang saku" menyatakan bentuk sopan dari kata "kodzukai", dan penggunaan "o" pada kata kerja "tsukai" diikuti kata "nasai" menjadi "otsukainasai" yang berarti "gunakanlah" menyatakan bentuk perintah pada tingkat bahasa keigo atau bahasa menghormati lawan bicara. Klausa tersebut dikelompokkan kedalam varian 5. Variasi yang muncul, salah satunya dalam kata ungkapan perintah "otsukainasai" yang merupakan elemen predikator diterjemahkan dengan penambahan elemen komplemen " ini pada klausa "ambil ini".

Pengungkapan makna konotatif merupakan hal yang paling sulit dalam penerjemahan, penerjemah harus benar-benar paham tentang budaya, terutama pada ungkapan-ungkapan yang hanya dikenal pada bahasa sumber. Dalam upaya penerjemahan ungkapan ini sehingga dapat berterima sudah barang tentu dapat mengakibatkan variasi dalam penerjemahannya, seperti tampak pada klausa berikut ini:

(15) $\mathrm{T} 1$ :

$$
\begin{aligned}
& \text { 「お気の毒だって、好んで行くんな } \\
& \text { ら仕方がないですね」 } \\
& \text { O kinodoku datte, kononde iku } \\
& \text { n"nara shikataganaidesu ne” }
\end{aligned}
$$

T2: "Kenapa malang? Bukankah dia sendiri yang memilih pergi ke sana, jadi kenapa harus kasihan?"

Penerjemahan "o-kinokudatte" yang merupakan sebuah klausa simpleks imperatif positif terdiri dari predikator dan finit menjadi "Kenapa malang? Berarti telah terjadi perubahan tipe klausa, menjadi interogatif dengan variasi elemen adjung dan predikator. Ungkapan " $O$ kinokudatte" adalah ungkapan yang tidak dikenal dalam bahasa Indonesia, prinsip on menjadi penyebab dari munculnya ungkapan ini. Orang Jepang paling tidak menyukai perbuatan-perbuatan baik dari orang yang yang tidak begitu dikenalnya. Orang Jepang tidak suka untuk seenaknya menyandang arti utang budi yang terkandung dalam on. Kinodoku bermakna "oh, perasaan yang beracun ini", yang kadangkadang diterjemahkan sebagai "terima kasih", kadang sebagai "saya minta maaf", dalam berutang kadang sebagai "saya merasa seperti orang yang bermuka tebal. Hasil wawancara dengan informan tentang hal ini memberikan kepastian tentang hubungan budaya dan ungkapan tersebut. Junko higashi mengatakan bahwa ungkapan ini sangat tergantung pada konteks. Ungkapan ini digunakan pula pada saat seseorang merasa malu terhadap orang yang belum dikenal saat menawarkan bantuannya. Perasaan malu disebabkan karena sebagai orang Jepang telah didahului oleh orang yang belum dikenal dalam berbuat kebaikan. Bagi Yasuhisa 
Adachi, on dapat diwujudkan dengan menjaga dan memelihara anak-anak dengan baik sebagai cara membalas kebaikan-kebaikan yang telah ia terima hingga sekarang. Penerjemahan yang tidak tepat pada ungkapan ini akan menghilangkan makna yang dimaksudkan yaitu untuk mengungkapkan kegelisahan penutur dalam menerima on. Penjelasan singkat tersebut menunjukkan bahwa variasi KMI pada T2 terkait dengan sistem makna denotatif dan konotatif disebabkan oleh dua faktor, yaitu faktor linguistik dan nonlinguistik, khususnya faktor budaya.

\section{Pengaruh Variasi KMI terhadap Kesepadan- an Makna Teks Terjemahan}

Dari hasil analisis yang dilakukan, variasi KMI tersebut sebagian besar tidak memicu perubahan makna. Namun ada juga yang memicu perubahan makna. Makna dalam hal ini tentu saja tidak mengacu pada makna yang terbatas pada klausa-klausa yang dianalisis, melainkan makna teks sebagai konteks dari klausa-klausa tersebut. Bahkan ketika variasi atau perubahan itu memiliki tingkat variasi tertinggi, bernilai 6 (enam), yang berarti pemunculan makna baru atau penghilangan satu realisasi makna klausa, seperti tampak pada data berikut:

(16) T1 : 広い所だ。(hiroi tokoroda)

T2 : (tidak diterjemahkan)

Tampak pada klausa tersebut, jelas satu realisasi makna telah dihilangkan sama sekali. Untuk menilai efek perubahan realisasi itu, klausa tersebut perlu ditempatkan pada konteks yang mengelilinginya, seperti dalam kutipan berikut.

(17) $\mathrm{T} 1$ :

おれだって人間だ、教頭ひとりで借

り切った海じやあるまいし。

(Ore datte ningenda, kyōtō hitori de karikitta umi jaarumaishi.)

T2: Berhubung aku juga manusia dan si Kemeja Merah tidak menyewa seluruh lautan, aku merasa setidaknya seekor tuna kecil akan merasa berkewajiban terkail tali pancingku.

Dalam T2 tidak secara langsung menyebutkan deskripsi bagaimana luasnya laut itu, tetapi penambahan kata "seluruh" pada frasa "seluruh lautan" telah menggambarkan tentang laut merupakan tempat yang luas. Sehingga, penghilangan satu klausa deskripsi pelengkap tersebut tidak terlalu mengganggu pesan "tempat yang luas". Artinya, variasi dengan nilai 6 tersebut tidak berpengaruh terhadap keutuhan pesan yang hendak disampaikan oleh penulis T1dalam bagian wacana tersebut.

(18) T1: (tidak ada ekspresi kebahasaan)

T2: Aku tidak punya uang cukup untuk tinggal lama di sana, jadi nantinya aku bakal harus pindah lagi.

Penciptaan klausa baru yang dilaku-kan penulis T2, seperti tampak pada klausa (18) berkaitan dengan konstektual yang berlaku pada T2. Penulis berupaya mendeskripsikan "tekazuu" atau "kesusahan" yang klausa sebelumnya atau data sebelumnya. Dengan mengabaikan alasan bahwa penerjemahan T2 merupakan penerjemahan tidak langsung dari T1, dapat dikatakan penulis T2 menciptkan klausa ini untuk mengingatkan kembali pembaca bahwa Botchan sedang mengalami kesulitan keuangan yang dijelaskannya pada klausa "Bahkan gaji penuhku mungkin tidak akan bisa menutupi biaya sewanya". Peciptaan klausa ini memberi pengaruh positif terhadap pembaca $\mathrm{T} 2$ dengan menyampaikan informasi lama.

Selain variasi tersebut, terdapat variasi bernilai 1 (satu) sampai 5 (lima) yang berupa perbedaan jumlah elemen fungsi antara $\mathrm{T} 1$ dan T2 sesuai dengan variasi yang dimaksud. Seperti telah dikemukakan pada uraian pada masingmasing variasi tersebut, dapat disimpulkan bahwa sebagian besar perbedaan jumlah elemen adalah karena faktor linguistik dan budaya antara T1 dan T2. Pada perbedaan elemen antara T1 dan T2 karena adanya penambahan elemen subjek pada T2 tidak memberi pengaruh pada makna pada $\mathrm{T} 2$.

(19) T1:また小使を呼んで、「さっきのバッ タを持ってこい」と云ったら、「も う掃溜へ棄ててしまいましたが、拾 って参りましょうか」と聞いた。

Mata kodzukai o yonde, 'sakki no batta o motte koi" to yuttara, 'mō hakidame e sutete shimaimashitaga, hirotte mairimashou ka" to kiita.

T2: Aku pun memanggil si penjaga sekolah dan menyuruhnya membawa masuk kembali belalang-belalang tadi. Dia menjawab dia sudah membuang mereka ke tumpukan sampah dan bertanya apakah dia perlu ke sana dan mengambilnya lagi?,

Dengan demikian, penambahan atau penghilangan elemen pada sebagian besar klausa T2 tidak selalu menimbulkan perubahan makna 
teks. Makna inti yang terkemas dalam T1 masih dapat diperoleh dalam T2. Hal ini terjadi karena terkadang sebuah teks mengungkapkan satu makna dengan berbagai realisasi yang berbeda, dan T2 menyajikannya dengan cara berbeda, tanpa mengorbankan pesan/makna inti yang dimaksud. Berbagai jenis variasi yang ditemukan secara umum tidak menimbulkna perbedan makna. Variasi-variasi yang tergolong tinggi pun demikian, meskipun perwujudannya berbeda, tetapi masih mengandung makna inti yang serupa.

\section{SIMPULAN}

Berdasarkan analisis data dapat ditarik kesimpulan berikut sebagai jawaban-jawaban dari pertanyaan penelitian yang telah dirumuskan.

Pertama, wujud variasi keluasan makna inter-personal antara T1 dan T2 mencakup semua kemungkinan variasi dari varian nol hingga varian 6. Artinya, terjadi penambahan dan pengurangan atau penghilangan semua jenis elemen, dari subjek, predikator, komplemen, adjung dan finit, dan klausa.

Kedua, penambahan elemen terjadi pada semua elemen, penambahan elemen subjek mendominasi variasi KMI pada T2. Pemahaman yang sama antar pelibat T1 tentang subjek atau topik sehingga tidak perlu mengulang topik atau subjeknya.

Ketiga, penambahan elemen komplemen pada T2 sebagian besar disebabkan karena perbeda-an gramatika dalam pembentuk predikator. Penambahan adjung pada klausa T2 meru-pakan akibat dari ketiadaan finit dalam struktur kalimat bahasa Indonesia. Finit dalam bahasa Jepang terkait dengan kala. Penambahan predikator pun ditemukan pada klausa T2.

Keempat, pengurangan pun terjadi pada semua elemen baik elemen mood maupun residu. Pengurangan yang terjadi pada varian enam adalah pengurangan pada tingkat klausa. Pengurangan klausa lebih dominan dari penciptaan klausa baru terjadi pada T2. Temuan ini dapat dimaknai bahwa penerjemahan klausa yang terjadi disebabkan karena penerjemah memiliki keleluasaan dalam mewujudkan makna terkait dengan dengan batasan konteks baik perbedaan sistem bahasa maupun pertimbangan-pertimbangan dalam membentuk hubungan antar pelibat.

Kelima, variasi yang paling banyak di antara varian nol sampai dengan varian enam adalah pada varian lima, sebanyak 579 klausa. Namun berdasarkan penghitungan secara keseluruhan klausa sebanyak 2562 klausa, 1115 klausa atau 43,58\% merupakan tingkat variasi rendah. Sekalipun perbedaan prosentase kecil, atau hanya $11 \%$ saja dengan jumlah klausa pada tingkat variasi sedang, dan perbedaan kurang dari $20 \%$ merupakan tingkat variasi tinggi.

Keenam, faktor-faktor yang menyebabkan terjadi variasi KMI antara T1 dan T2 disebabkan dua faktor, yaitu faktor linguistik dan nonlinguistik.

Ketujuh, faktor linguistik adalah faktorfaktor yang disebabkan karena adanya perbedaan sistem kebahasaan antara kedua bahasa. Perbedaan sistem kebahasaan antara lain adalah struktur kalimat atau pola kalimat dalam realisasi mood, penggunaan partikel pada kalimat bahasa Jepang, penggunaan kala dan aspek.

Kedelapan, faktor nonlingusitik difokuskan pada konteks situasi terutama konteks budaya dari kedua teks. Pada konteks budaya variasivariasi menunjukkan adanya perbedaan menyampaikan pesan terkait pada hubungan antar persona berupa prinsip dan sikap bahasa pelibat dan tingkat kesantunan bahasa. Misalnya pada klausa varian 6 yang telah dijelaskan pada sub bahasan sebelumnya, yaitu berupa penghilangan klausa “広い所だ。(hiroi tokoroda).” Yang berarti tempat yang luas. Pengungkapan makna tempat yang luas sebagai predikator telah diuraikan pada klausa T2 secara implisit dalam kata "seluruh lautan". Dalam budaya berbahasa Jepang, ketiadaan subjek pada klausa tersebut merupakan bentuk menjaga hubungan persona pelibat tentang adanya kesamaan pemahaman topik pembicaraan, selain itu penggunaan "da' menunjukkan penutur menempatkan dirinya sejajar atau pada tingkat kesantunan bahasa tidak halus. Dalam klausa T2, hal-hal tersebut tidak tampak dan tingkat bahasa yang digunakan merupakan bahasa yang dapat digunakan pada bahasa fomal maupun informal.

Variasi-variasi KMI yang terjadi sebagai upaya untuk mempertahankan makna antara $\mathrm{T} 1$ dan T2, sehingga perbedaan jumlah elemen makna interpersonal tidak berpengaruh pada perubahan makna inti. Kemunculan klausa baru berfungsi untuk memperjelas makna-makna yang tersirat. Variasi makna direalisasikan dalam klausa baik berupa penambahan dan pengurangan atau penghilangan elemen dapat menimbulkan perubahan makna. Namun, dari teks satu dengan teks yang lainnya yang saling berkorelasi tetap menghasilkan makna-makna yang sepadan dan selaras. 


\section{DAFTAR PUSTAKA}

Baker, M. (1992). In other words: A course on translation. New York: Taylor and Francis e-Library

Bell, R.T. (1991). Translation and translating: Theory and practice. New York: Longman Inc

Benedict, R. (1982). Pedang samurai dan bunga seruni: Pola-pola kebudayaan Jepang (Terjemahan Pamudji). Tokyo: the Charles E. Tuttle Company. (Buku asli diterbitkan tahun 1979)

Chino, N. (1991). All about particles. Tokyo: Kodansha International

Halliday, M.A.K \& Hasan, R. (1992). Bahasa, konteks, dan teks: Aspek-aspek bahasa dalam pandangan semiotik social. (Terjemahan Asruddin Barori Tou). Melbourne: Deakin University. (Buku asli diterbitkan 1985)

Larson, M.L. (1984). Meaning based translation: A guide to cross language equivalence. New York: University Press of America

Rubin, J. (1993). Eufemisme dalam bahasa Jepang: Pandangan baru terhadap masalah-masalah perenial (terjemah-an Nasir Ramli). Jakarta: Kesaint Blanc. (Buku asli diterbitkan tahun 1992)

Sinar, Tengku Silvana. (2008). Teori dan analisis wacana. Medan: Pustaka bangsa Press 